\title{
FOREST TYPES OF PASHUPATI SACRED GROVE, KATHMANDU, NEPAL
}

\section{L.J. Shrestha and M. Devkota}

\section{ABSTRACT}

A year round phytosociological study was carried out in 2012 to study different forest types in Pashupati Sacred Grove in Kathmandu Valley. Concentric circular plots ( $n-19)$ were laid down along eight parallel transects, $100 \mathrm{~m}$ apart from each other, traversing north and south passing through various vegetations. Our results showed that the grove had experienced change in forest types over the time period. Three forest types namely Schima-Pyrus, Moist (MyrsinePersea) and Mixed (Quercus-Myrsine) were identified based on the importance value Index (IVI) of tree species instead of Myrsine-Schima forest which had once dominated the grove. Tree density greatly changed in different forest types and showed strong correlation between canopy cover and tree density, supporting the results of previous studies.

Key words: phyto-sociology, Importance Value Index, correlation, diversity, conservation

\section{INTRODUCTION}

Sacred grove has been defined as "A tract of virgin forest harboring rich biodiversity, protected by the local people based on the ground of indigenous cultural and religious beliefs, and taboos". (Khumbongmayumi et al. 2005) and have been proved as the repositories of rare and endemic species as the remnant of the primary forest left untouched by the local inhabitants (Anthwal et al. 2006). The role of sacred groves in the conservation of biodiversity has long been recognized (Gadgil and Vartak 1976, Haridasan and Rao 1985, Khan et al. 1997) and it has been believed that sacred virgin forests date back to several thousands of years when human society was in the primitive state and all forms of vegetation in the sacred groves were supposed to be under the protection of the reigning deity of that grove, and the removal of even a small twig is taboo.

Nepal's Forest Act 1992 has defined a religious forest as "A forest area that has been legally handed over to a legally registered religious groups, communities or organizations to carry out and continue traditional religious activities by sustainably utilizing its resources as described in its management plan". In Nepal sacred groves have received considerable attention in conserving small patches of forest from socio-cultural and religious perspective but in recent times they are facing severe threats and are in verge of destruction. In an intensive study on the sacred groves of Kathmandu Valley, Mansberger (1991) has reported that Pashupati sacred grove is facing serious forest conservation challenges. A year round phyto-ecological assessment of Pashupati Sacred Groves was conducted in 2012 to identify the existing forest types within the grove. 


\section{STUDY AREA}

The study was carried out in Pashupati Sacred Grove (83.55 ha) located in the suburbs of Kathmandu City between $27^{\circ} 42^{\prime} 25^{\prime \prime}$ to $27^{\circ} 42^{\prime} 36^{\prime \prime} \mathrm{N}$, and $85^{\circ} 20^{\prime} 12^{\prime \prime}$ to $85^{\circ} 21^{\prime} 29^{\prime \prime} \mathrm{E}$ at an elevation of $1,300 \mathrm{~m}$. Based on historical facts it has been estimated that the grove is 1400 years old (Mansberger 1991) and has been considered as a bio-cultural landscape having close relationship with religious, socio-cultural beliefs, taboos and conservation practices. Pashupati Area Development Trust (PADT) has undertaken management responsibility of the sacred forest. Long back the grove was dominated by Choerospoandias axillaris (Nepalese Hog Plum) tree and due to that even today it is also known as Sleshmantak Forest but since that time lots of changes have occurred in the forest composition and species diversity.

\section{MATERIALS AND METHODS}

Parallel transects $(n=8) 150$ m apart from each other traversing north-south direction incorporating each forest types of the study area were prepared with the help of Google earth image. Coordinates of each transects thus laid were recorded and location of the field plot measurement were also selected at the interval of $100 \mathrm{~m}$ in each transect. The coordinates (latitude and longitude) of selected plot were noted down separately. Distance between quadrates varied with the size of unit to be sampled, but was always a minimum of 50 paces apart. Sampling was conducted at least $25 \mathrm{~m}$ from the border of different forest types.

Concentric Circular Sample Plots (CCSPs) were used to collect the field data (FRA 2010). The central point of CCSP was identified by using Geographic Position System (GPS) included with already identified coordinates from Google Earth images. The circles of a CCSP with different radii and diameter thresholds were centered at the same point. The outermost plot was used for tallying bigger trees, whereas inner plots are used for measuring trees belonging into smaller size classes, respectively. The innermost circle was used for assessing shrubs and for counting natural regeneration by counting the number of seedlings by species. The CCSP consist of four circular plots: plot with the radius of $20 \mathrm{~m}\left(A=1257.1 \mathrm{~m}^{2}\right)$ all big size trees with $\mathrm{DBH} \geq 30 \mathrm{~cm}$ were measured, plot with the radius $15 \mathrm{~m}$ (area: $707.1 \mathrm{~m}^{2}$ ) trees with $\mathrm{DBH}$ $20.0 \mathrm{~cm}$ to $30.0 \mathrm{~cm}$ were measured, the third plot with the radius $8 \mathrm{~m}$ (area: $201.1 \mathrm{~m}^{2}$ ) trees with $\mathrm{DBH}$ from $10.0 \mathrm{~cm}$ to $20.0 \mathrm{~cm}$ were measured, fourth plot with the radius $4 \mathrm{~m}$ (area: 50.2 $\mathrm{m}^{2}$ ) trees with $\mathrm{DBH}$ from $5.0 \mathrm{~cm}$ to $10.0 \mathrm{~cm}$ were measured. Canopy covers of the plots were measured with the help of Densiometer. The height and DBH (diameter at breast height) of trees (woody plant with single bole, $>5 \mathrm{~cm} \mathrm{DBH}$ and $>1.3 \mathrm{~m}$ height) were measured with the help of Vertex IV, Transponder T3 and DBH tape.

Importance values index (IVI) of individual trees species available in the particular vegetation were calculated by adding the relative values of frequency, density and dominance. Relative dominance of trees was determined by calculating the basal area. Name of each forest type was determined by ordering the Importance values of each tree species. The name of particular vegetation was provided from the name of plant with highest importance value.

\section{RESULTS AND DISCUSSION}

From the phyto-sociologial analysis three types of forest were recorded in Pashupati Sacred 
J. Nat. Hist. Mus. Vol. 27, 2013

Grove. They were Schima-Pyrus Forest, Myrsine-Persea Forest and Quercus-Myrsine Forest. Schima-Pyrus (Chilaune-Mayal) Forest

This forest occupied 20.9 ha area incorporating Mirgasthali Deer park (4.8 ha). The average tree height of this forest was $15.2 \mathrm{~m}$ with $40.9 \mathrm{~cm}$ of average diameter. In this forest total 14 tree species were recorded with the density of 318 trees per ha. The height of tree in this forest was reached up to $35 \mathrm{~m}$ (Araucaria bidwilii). In this forest Schima wallichii was found most important tree (IVI=81.4) followed by Pyrus pashia (IVI = 51.5) (table 1). The canopy coverage of the tree of this forest was $55 \%$.

Mysrine-Persea (Moist) Forest

A total of 11 tree species with the density of 593 trees per ha were recorded from this forest. It geographical area covered by this forest was 22.5 ha. The average tree height was $11.7 \mathrm{~m}$ with $30.7 \mathrm{~cm}$ of average diameter. The maximum height of tree recorded from this forest was $25.9 \mathrm{~m}$. From phyto-sociological analysis the more important tree of this forest was Myrsine capitellata (IVI=142.9) followed by Persea odoratissima (IVI=41.5) (table 1). Tree canopy cover of this forest was $80.96 \%$.

Quercus-Myrsine (Mixed) Forest

The study revealed the presence of 5 tree species with 677 trees per ha in this forest. The geographical area occupied by the forest was 40.1 ha. The average height of tree was $12.6 \mathrm{~m}$ with $28.5 \mathrm{~cm}$ of average diameter. The more important tree of this forest was Quercus glauca $(\mathrm{IVI}=138.5)$ followed by Myrsine capitellata (IVI=56.2). The maximum height of tree in this forest was $20 \mathrm{~m}$. Canopy cover of the tree in this forest was $85.8 \%$.

Most of the previous studies regarding the Pashupati Sacred Groves mainly focused its environment and conservation of forest (Marriot 1978, Bajracharya et al. 1988, Tandon 1989). The area is also famous for the commercially valuable medicinal plants (Joshi et al. 1998).

Pashupati Sacred Grove, also known as Sleshmantak forest, used to be dominated by Choerospoandias axillaris trees in the past. Previously only one forest type Myrsine-Schima was identified by Shrestha (2001). Three forest types have been identified by the current study and Choerospoandias axillaris was not identified as dominant tree for none of these forest types.

Deer Park of this forest is located in Mrigasthali area. In this park 2 Barking deers (Muntiacus muntjak) and 10 Chitals (Axis axis) and 20 Blackbucks (Antelope cervicarpa) were reintroduced in 2004 by Pashupati Area Development Trust (Shrestha 2009). The forest of Mrigasthali was considered as dying forest patch due to the heavy pressure from the reintroduced deer (Ghimire and Shrestha 2009) whose population has gone up to 150 according to Pashupati Area Development Trust. Current result also supported the negative impact of the deer park for forest cover. The tree canopy cover in this patch of forest is less (55\%) than other forest types. Current study reflected that tree density is different according to the forest types. The density of tree also related to the tree canopy coverage of the forest. So, the canopy coverage is one of the indicators of the forest degradation. There was less canopy cover and less density of tree in degraded forest of Mrigasthali (Ghimire and Shrestha 2009). Current study provided the similar 
result that there are strong correlation between tree canopy cover and tree density $(r=0.997)$. The sacred groves in Kathmandu Valley are bio-cultural landscape, which have deeply rooted biological, cultural, religious and historical significances in the local communities. Regardless of strong religious beliefs which has always contributed in the conservation activities in Nepal the groves is getting pressure from local communities. Mansberger (1991) and Ingles (1994), in their extensive study, mention that due to weakening of religious beliefs in Nepal sacred groves of the country are on the way to extinction due to various threats. Registration of only 36 sacred groves covering an area of 2056 ha forest in Nepal (DoF 2013) is also an indication of inadequate conservation policy and action plan of Government of Nepal.

\section{ACKNOWLEDGEMENTS}

We would like to thank Tribhuvan University for providing study opportunity, University Grants Commission of Nepal for financial support to conduct research, Pashupati Area Development Trust for providing research permission, FRA Nepal for providing equipment to conduct survey, Ms. Babita Shrestha and Rajol Shrestha for their help during field work.

\section{Abbreviation used}

DoF- Department of forest, FRA - Forest Resource Assessment, GoN - Government of Nepal, IVI - Importance value index, RD - Relative density, RDo - Relative dominance, RFr - Relative frequency.

\section{REFERENCES}

Anthwal, A., R., C. Sharma and A. Sharma. 2006. Sacred groves: traditional way of Conserving Plant Diversity in Garhwal Himalaya, Uttaranchal. The Journal of American Science, 2(2): 35-43. Bajracharya, D., G.P.S Ghimire and P.K. Jha, 1988. Environmental observation on Pashupati area. In Jha, J. S., Pradhananga, T. M., Khanal, S. N. and Thapa, A. (eds). Proceedings of the Seminar on Environmental Issues of Pashupati Area, RONAST, pp 54-64.

DoF, 2013. An Introduction to Department of Forest. Ministry of Forest and Soil Conservation, Kathmandu, Nepal.

FRA, 2010. Draft Field Manual for forest inventory. Forest Resource Assessment (FRA) Nepal, Kathmandu, Nepal.

Gadgil M. and V. D. Vartak. 1976. The sacred groves of Western Ghats in India. Economic Botany, 30:152-160.

Ghimire, B. and S. Shrestha, 2009. Why play God in Pashupati? An impact study of in introduced Deer and Antelope populations on the sacred forest. Resources Himalaya Foundation, Kathmandu.

Haridasan, K. and R.R. Rao, 1985. Forest Flora of Meghalaya, Vol. 1. Bishen Singh and Mahendrapal Singh, Dehra Dun.

Ingles, A.W., 1994. The influence of religious and rituals of forest conservation in Nepal. Discussion paper. Nepal Australia Community Forestry Project. Kathmandu, Nepal. 
Joshi.S., S. Vaidya and I. Shrestha,1998. Contribution to the medicinal flora of Pashupati area of Kathmandu Valley. Research Division, Tribhuvan University, Kathmandu, Nepal.

Khan, M.L., S. Menon and K.S. Bawa. 1997. Effectiveness of the protected area network in biodiversity conservation: a case study of Meghalaya state. Biodiversity and Conservation, 6:853-868.

Khumbongmayum, A.D., M.L. Khan and R.S. Tripathi, 2005. Sacred groves of Manipur, northeast India: biodiversity value, status and strategies for their conservation. Biodiversity and Conservation, 14:1541-1582.

Mansberger, J.R., 1991. Ban yatra: a bio- cultural survey of sacred forest in Kathmandu valley. Ph.D. Thesis, University of Hawaii, USA, 330 p.

Marriot, B.M., 1978. A preliminary report on the feeding behavior of Rhesus monkey (Macaca mulatta) in Kathmandu, Nepal. Nature Annual, Nepal Nature Conservation Society, Kathmandu, II:68-72.

Shrestha, S., 2001. An ecological study of trees of Shleshmantak forest, Pashupati Development Area, Kathmandu. MSc. Dissertation, Central Department of Botany, Tribhuvan University, Kirtipur, Kathmandu, Nepal.

Shrestha, S., 2009. Destroying a remnant sacred forest, Resources Himalaya Foundation, XVI:3.

Tandon, G.,1989. Devpatan stith bhagwan shree Pashupatinath mandir ko adhyayan. Ph. D. Thesis, Department of Humanities and Sociology, Tribhuvan University, Nepal.

\section{Table 1. Composition of forests in Pashupati sacred grove.}

\begin{tabular}{|c|c|c|c|c|c|c|c|c|c|c|c|c|c|}
\hline \multirow{2}{*}{ SN } & \multirow{2}{*}{ Species } & \multicolumn{3}{|c|}{$\begin{array}{l}\text { Schima-Pyrus } \\
\text { forest }\end{array}$} & \multicolumn{4}{|c|}{$\begin{array}{l}\text { Quercus-Myrsine } \\
\text { forest }\end{array}$} & \multicolumn{5}{|c|}{ Myrsine-Persea forest } \\
\hline & & RFr & RD & RDo & IVI & $\mathrm{RFr}$ & RD & RDo & IVI & $\mathrm{RFr}$ & RD & RDo & IVI \\
\hline 1. & Schima wallichii (DC.) Korth & 18.92 & 38.4 & 24.1 & 81.4 & 25.0 & 15.5 & 14.4 & 54.9 & 16.7 & 3.9 & 4.0 & 24.6 \\
\hline 2. & Eurya acuminata DC. & 2.70 & 0.3 & 0.4 & 3.4 & - & - & - & - & - & - & - & - \\
\hline 3. & Zizyphus incurva Roxb. & 5.41 & 2.2 & 1.2 & 8.8 & - & - & - & - & - & - & - & - \\
\hline 4. & Syzygium cumini (L.) Skeels. & 5.41 & 1.1 & 1.4 & 8.0 & 20.0 & 12.7 & 11.6 & 44.3 & 12.5 & 3.4 & 3.4 & 19.3 \\
\hline 5. & $\begin{array}{l}\text { Stranvaesia nussia (D.Don) } \\
\text { Decne. }\end{array}$ & 5.41 & 0.6 & 1.3 & 7.2 & - & - & - & - & 4.2 & 1.7 & 1.6 & 7.5 \\
\hline
\end{tabular}




\begin{tabular}{|l|l|l|l|l|l|l|l|l|l|l|l|l|l|}
\hline 6. & Myrsine semiserrata Wall. & - & - & - & - & - & - & - & - & 4.2 & 8.3 & 8.2 & 20.7 \\
\hline 7. & $\begin{array}{l}\text { Myrica esculenta Buch-Ham. } \\
\text { ex. D. Don. }\end{array}$ & - & - & - & - & - & - & - & - & 4.2 & 0.3 & 0.3 & 4.8 \\
\hline 8. & $\begin{array}{l}\text { Persea odoratissima Ness } \\
\text { in Wall. }\end{array}$ & 13.51 & 5.3 & 8.1 & 26.9 & 5.0 & 0.7 & 0.6 & 6.3 & 16.7 & 12.4 & 12.4 & 41.5 \\
\hline 9. & Celtis australis L. & 5.41 & 0.6 & 0.9 & 6.8 & - & - & - & - & - & - & - & - \\
\hline 10. & $\begin{array}{l}\text { Choerospondias axillaris } \\
\text { (Roxb.) Burtt \& Hill. }\end{array}$ & - & - & - & - & - & - & - & - & 4.2 & 1.9 & 1.8 & 7.9 \\
\hline 11. & $\begin{array}{l}\text { Pyrus pashia Buch-Ham. ex. } \\
\text { D. Don. }\end{array}$ & 13.51 & 19.5 & 18.5 & 51.5 & - & - & - & - & 4.2 & 0.8 & 0.8 & 5.8 \\
\hline 12. & Araucaria bidwilli Hook. & 2.70 & 2.5 & 4.1 & 9.3 & - & - & - & - & - & - & - & - \\
\hline 13. & $\begin{array}{l}\text { Castanopsis tribuloides } \\
\text { (Sm.) A. DC. }\end{array}$ & 2.70 & 0.6 & 0.2 & 3.5 & - & - & - & - & 8.3 & 3.6 & 3.7 & 15.6 \\
\hline 14. & Myrsine capitellata Wall. & 13.51 & 4.2 & 4.3 & 21.9 & 25.0 & 14.6 & 16.6 & 56.2 & 16.7 & 63.1 & 63.1 & 142.9 \\
\hline 15. & Quercus glauca Thunb. & 5.41 & 1.1 & 1.7 & 8.2 & 25.0 & 56.6 & 56.9 & 138.5 & 8.3 & 0.8 & 0.8 & 9.9 \\
\hline 16. & $\begin{array}{l}\text { Hymenodictyon excelsum } \\
\text { (Roxb.) Wall. }\end{array}$ & 2.7 & 6.9 & 6.7 & 16.3 & - & - & - & - & - & - & - & - \\
\hline
\end{tabular}

\section{AUTHOR'S ADDRESS}

\section{Laxmi J. Shrestha and Mohan Devkota}

Department of Botany, Amrit Campus, Tribhuvan University, Kathmandu, Nepal (email: joshilaxmi@hotmail.com) 